\title{
PENGENALAN KONSEP SAINS PADA ANAK KELOMPOK B TK PERTIWI LOMBE
}

\author{
Nurhayati \\ Jurusan PG-PAUD, FKIP Universitas Halu Oleo.Jln. H.E.A Mokodompit, Kendari 93232, Indonesia. \\ E-mail: zainuddinnurhayati@gmail.com, Telp: 085696506712
}

\begin{abstract}
Abstrak
Tujuan dari penelitian ini adalah untuk mendeskripsikan pelaksanaan pembelajaran untuk mengenalkan konsep sains pada anak TK B dan untuk menganalisis perkembangan kemampuan anak dalam mengenal sains. Jenis penelitian ini adalah Quasi Eksperimen tanpa pembanding atau eksperimen semu dengan desain penelitian yang digunakan adalah one group pretest-posttest design. Subyek dalam penelitian adalah anak kelompok B TK Pertiwi Lombe yang berjumlah 20 orang. Hasil penelitian ini diantaranya: (1) pelaksanaan pembelajaran untuk mengenalkan konsep sains pada anak kelompok B TK Pertiwi Lombe dilakukan melalui pembelajaran dengan percobaan sains secara sederhana sesuai dengan karakteristik anak dan kondisi sekolah, (2) kemampuan anak dalam mengenal sains pada kelompok B TK Pertiwi Lombe mengalami perkembangan dengan skor rata-rata 45 dan secara statistik cukup signifikan dengan nilai sig $=0,000<0,05$.
\end{abstract}

Kata kunci: Konsep, Pembelajaran, Sains.

\section{THE INTRODUCTION OF SCIENCE CONCEPT FOR CHILDREN IN GROUP B TK PERTIWI LOMBE}

\begin{abstract}
The purpose of this study was to describe the implementation for introducing the concept of science in kindergarten $B$ and to analyse the development of the ability of the child to know in science. This type of research is Quasi Experiment without comparison with pseudo experiments or research design used was one group pretest - posttest design. The subjects in the study was the son of the Group B TK Pertiwi Lombe totalling 20 people. The results of this study are: (1) implementation of learning to introduce science concepts in children Group B TK Pertiwi Lombe was done through learning with simple science experiments in accordance with the characteristics of the child and the condition of the schools, (2) the ability of the child to know in science on the Group B TK Pertiwi Lombe progression with an average score of 45 and statistically significant gains value sig $=0.000<$ 0.05 .
\end{abstract}

Keywords: Concepts, Learning, Science.

\section{PENDAHULUAN}

Pendidikan Anak Usia Dini merupakan jembatan antara lingkungan keluarga dengan masyarakat yang lebih luas yaitu Sekolah Dasar dan lingkungan lainnya dengan tujuan untuk memfasilitasi pertumbuhan dan keterampilan anak secara menyeluruh atau menekankan pada pengembangan seluruh aspek kepribadian anak. Oleh karena itu pendidikan untuk anak usia dini khususnya di Taman Kanak-Kanak perlu menyediakan berbagai kegiatan yang dapat mengembangkan berbagai aspek keterampilan anak. Hal ini sejalan dengan pendapat Osakwe
(2009) dalam penelitiannya yang menunjukan bahwa siswa yang telah mengikuti pendidikan prasekolah tampil lebih baik pada aspek keterampilan kognitif, psikomotorik, dan keterampilan sosial dari pada siswa yang tidak mengikuti pendidikan prasekolahnya. Osakwe menyarankan bahwa pendidikan anak usia dini harus didorong oleh pemerintah dengan memberikan fasilitas pendidikan pra dasar (ruang kelas, bahan pengajaran, dan peralatan) yang diperlukan untuk keberhasilan program dan harus ada kampanye pencerahan yang tepat tentang pentingnya pendidikan anak usia dini. Dalam hal ini orang tua juga harus terlibat 
dalam pengalaman pendidikan dini anak-anak mereka dengan menyediakan bahan yang diperlukan.

Anak pada TK B berdasarkan perkembangan kognitif berada pada tahapan operasional konkret. Pada rentang usia tersebut anak mulai menunjukkan perilaku belajar seperti (1) mulai memandang dunia secara objektif, bergeser dari satu aspek situasi ke aspek lain secara reflektif dan memandang unsur-unsur secara serentak, (2) mulai berpikir secara rasional, (3) menggunakan cara berpikir operasional untuk mengklasifikasikan bendabenda, (4) membentuk dan menggunakan keterhubungan aturan-aturan, prinsip ilmiah sederhana, dan menggunakan hubungan sebab akibat.

Proses kegiatan pembelajaran dengan mengembangkan cara belajar siswa aktif, siswa menemukan sendiri, menyelidiki sendiri, maka hasil yang diperoleh akan setia dan tahan lama dalam ingatan. Pengalaman belajar yang ditemukan sendiri anak merupakan pengalaman belajar yang betul-betul dikuasai dan mudah digunakan atau ditransfer dalam situasi lain. Dengan kata lain pembelajaran akan bermakna apabila siswa terlibat dan mengamati langsung secara aktif baik fisik, mental dan emosional selama proses pembelajaran.

Pengembangan potensi yang dimiliki anak perlu dilakukan secara intensif sedimikian rupa termasuk didalamnya mengembangkan kognitif terutama pengenalan sains yang memiliki peranan yang sangat penting dalam membantu mengembangkan dasar kemampuan dan pembentukan sumber daya manusia yang diharapkan ke depan. Dalam pengenalan sains, guru perlu memahami karakteristik anak dan lingkungan dan menjadi titik tolak pembelajaran agar anak mudah memahami konsep sains sebagaimana yang dikemukakan oleh Akerson dan Donnelly (2011) bahwa mengajarkan sains pada anak usia dini tidak harus menunggu anak berkembang. Menghubungkan sains dengan ilmu pengetahuan sejak usia awal akan memungkinkan siswa untuk terus mengembangkan sains dari waktu kewaktu hingga meningkatkan pemahaman sains sampai lulus SMA.

Sains sangatlah dekat dengan kehidupan anak usia dini. Bagi anak-anak belajar sains adalah segala sesuatu yang menakjubkan, sesuatu yang ditemukan dan dianggap menarik serta memberi pengetahuan atau merangsangnya untuk mengetahui dan menyelidikinya sehingga dengan belajar sains mendapatkan suatu kebenaran serta mengembangkan kemampuan berfikirnya. Belajar sains sejak dini dimulai dengan memperkenalkan alam dengan melibatkan lingkungan untuk memperkaya pengalaman anak. Piaget dalam Suyanto, (2005: 76), mengungkapkan kegiatan pengenalan sains untuk anak usia 5-6 tahun sebaiknya disesuaikan dengan tingkat perkembangan anak, anak usia TK berada pada fase perkembangan praoperasional dan konkret operasional. Untuk itu kegiatan sains sebaiknya memiliki kriteria yang disesuaikan dengan tingkat perkembangan tersebut, antara lain sebagai berikut:

1) Hubungan sebab-akibat terlihat secara langsung.

Anak usia 5-6 tahun masih sulit menghubungkan sebab-akibat yang tidak terlihat secara langsung karena pikiran mereka yang bersifat transduktif.

2) Memungkinkan anak melakukan eksplorasi.

$$
\text { Kegiatan sains sebaiknya }
$$
memungkinkan anak melakukan eksplorasi terhadap berbagai benda yang ada disekitarnya.

3) Memungkinkan anak mengonstruksi pengetahuan sendiri.

Kegiatan pengenalan sains tidak cukup dengan memberi tahu definisi atau namanama objek, tetapi memungkinkan anak berinteraksi langsung dengan objek dan memperoleh pengetahuan dengan berbagai indranya dari objek tersebut.

4) Memungkinkan anak menjawab persoalan "Apa" dari pada "Mengapa".

Keterbatasan anak menghubungkan sebab akibat menyebabkan ia sulit menjawab pertanyaan "mengapa". Pertanyaan tersebut harus dijawab dengan logika berpikir sebab akibat. Hal itu tidak akan bisa dijawab anak.

5) Lebih menekankan pada proses dari pada produk

Melakukan kegiatan eksplorasi dengan benda-benda di sekitar lebih menyenangkan bagi anak. Anak tidak berpikir hasilnya. Oleh karena itu, tidak perlu guru mengajari anak dengan berbagai konsep sains.

6) Memungkinkan anak menggunakan bahasa dan matematika

Anak dapat menceritakan hasil eksplorasinya kepada temannya melalui bahasa. Anak melakukan pengukuran, 
menggunakan bilangan, dan membaca angka (matematika).

7) Menyajikan kegiatan yang menarik (the wonder of science)

Sains menyajikan berbagai percobaan yang menarik seperti sulap. Anak TK yang masih memiliki pikiran magis (magical reasoning) akan sangat tertarik dengan keajaiban tersebut.

Nugraha (2008: 30) mengemukakan bahwa tujuan pembelajaran sains bagi anak dibagi menjadi tiga. Pertama, pendidikan sains diarahkan pada pengenalan dan penguasaan fakta, konsep, prinsip, teori maupun aspek-aspek lain yang terkait dengan hal-hal yang ditemukan dalam bidang sains itu sendiri. Kedua, dimensi sains proses yaitu tujuan diarahkan pada penguasaan keterampilan-keterampilan yang diperlukan dalam menggali dan mengenal sains. Ketiga, dimensi sains sikap, maksudnya adalah pengembangan pembelajaran sains pada anak usia dini secara bertahap diharapkan pada suatu pembentukan pribadi atau karakter (character building).

Kondisi pembelajaran sains yang terjadi pada TK Pertiwi Lombe khususnya anak kelompok B tidak sesuai dengan harapan tujuan pembelajaran sains. Hal ini ditunjukkan pengenalan sains belum optimal dilakukan dalam kegiatan pembelajaran, penggunaan metode pembelajaran yang belum efektif, guru dalam memberikan materi pelajaran hanya berupa pengenalan-pengenalan konsep secara abstrak tanpa memberikan contoh yang konkret dan alasan yang jelas serta tidak melibatkan kegiatan sains dalam proses pembelajaran, guru hanya membacakan buku teks yang dilanjutkan dengan pembahasan secara verbal yang mengakibatkan siswa tidak mempunyai kesempatan untuk terlibar sendiri dalam pembelajaran.

Pembelajaran sains penting diterapkan dalam kegiatan pembelajaran anak usia dini sehingga menghendaki seorang guru untuk memiliki kemampuan untuk mendesain sistem pembelajaran agar sains dapat dipahami anak dengan baik. Banyak metode yang dapat digunakan guru dalam mengenalkan sains pada anak TK tetapi harus diketahui metode yang efektif agar pembelajaran lebih bermakna bagi anak. Nugraha (2008: 31) mengemukakan bahwa seseorang dikatakan menganal sains apabila ia dapat menguasai, menggali dan mengungkap segala sesuatu yang yang terkait dengan alam dan permasalahannya. Prosedur dan teknik yang benar dalam mengenal alam dan fenomenanya diperkenalkan dengan cara atau proses mengungkap sains yang benar, seperti proses mengamati, menggolongkan, menalar, mengukur, menguraikan, menjelaskan, mengajukan pertanyaan penting tentang alam, merumuskan hipotesis, merancang penyelidikan termasuk eksperimen.

Suyanto (2005: 163) berpendapat bahwa pengenalan sains untuk anak usia dini dilakukan untuk mengembangkan kemampuan berikut: (1) eksplorasi dan investigasi, yaitu kegiatan untuk mengamati dan menyelidiki objek dan fenomena yang ada di alam; (2) mengembangkan keterampilan proses sains dasar, seperti melakukan pengamatan, pengukuran, menggunakan bilangan, dan mengkomunikasikan hasil pengamatan; (3) mengembangkan rasa ingin tahu, senang, dan mau melakukan kegiatan inkuiri dan discovery; (4) memahami pengetahuan tentang berbagai benda baik ciri, struktur, maupun fungsinya.

Permasalahan dalam penelitian yaitu: (1) bagaimana pelaksanaan pembelajaran untuk mengenalkan konsep sains pada anak kelompok B TK Pertiwi Lombe?, (2) bagaimana perkembangan kemampuan mengenal sains pada anak kelompok B TK Pertiwi Lombe?. Tujuan dari penelitian ini adalah untuk mendeskripsikan pelaksanaan pembelajaran untuk mengenalkan konsep sains pada anak TK B dan untuk menganalisis perkembangan kemampuan anak dalam mengenal sains.

Manfaat dari penelitian ini diantaranya: (1) bagi sekolah: sebagai inovasi pembelajaran pada satuan pendidikan Taman Kanak-Kanak untuk mengembangkan berbagai aspek perkembangan anak, (2) bagi guru: sebagai rujukan alternatif pembelajaran dalam mengenalkan sains sederhana pada anak usia dini, (3) bagi peneliti lainnya: dapat dijadikan rujukan untuk melakukan penelitian selanjutnya pada tempat, berbagai wilayah sekolah yang berbeda

\section{METODE}

Jenis penelitian ini adalah Quasi Eksperimen tanpa pembanding atau eksperimen semu dengan desain penelitian yang digunakan adalah one group pretest-posttest design yang tampak pada Tabel berikut ini.

Tabel 1. Desain Penelitian 


\begin{tabular}{|r|c|c|}
\hline Pretest & Treatment & Posttest \\
\hline $\mathrm{O}_{1}$ & $\mathrm{X}$ & $\mathrm{O}_{2}$ \\
\hline \multicolumn{3}{|c|}{ (Sugiyono, 2010) } \\
\hline
\end{tabular}

Treatment dalam penelitian adalah perlakuan dalam pembelajaran yang dilakukan pada satu kelompok eksperimen pada anak kelompok B TK Pertiwi Lombe. Penelitian ini dilaksanakan di TK Pertiwi Lombe Kecamatan Gu Kabupaten Buton. Subyek dalam penelitian adalah anak kelompok B TK Pertiwi Lombe yang berjumlah 20 orang.

Variabel dalam penelitian ini terdiri dari variabel terikat yaitu perkembangan kemampuan anak dalam mengenal sains dan variabel bebas yaitu pembelajaran sains. Teknik pengumpulan data yang digunakan dalam penelitian ini adalah menggunakan instrumen observasi terhadap anak dalam mengenal konsep sains.

Analisis data terhadap perkembangan kemampuan anak dalam mengenal sains menggunakan kategori pada Tabel 2 berikut ini.

Tabel 2. Kategori Kemampuan Anak Mengenal Sains

\begin{tabular}{cc}
\hline Persentase & Kategori \\
$76 \%-100 \%$ & Berkembang Sangat Baik \\
& (BSB) \\
$51 \%-75 \%$ & Berkembang Sesuai \\
& Harapan (BSH) \\
$26 \%-50 \%$ & Mulai Berkembang (MB) \\
$0 \%-25 \%$ & Belum Berkembang (BB) \\
\hline \multicolumn{2}{c}{ Anak dapat dikatakan telah mengenal }
\end{tabular}

konsep sains dengan baik jika persentase yang diperoleh lebih dari $50 \%$ berada pada kategori minimal tinggi. Sedangkan Uji statistik untuk mengetahui signifikansi perkembangan kemampuan anal dalam mengenal konsep sains menggunakan rumus berikut ini (Supardi, 2013: 325):

$$
t=\frac{M_{d}}{\sqrt{\frac{\sum x_{d}^{2}}{n(n-1)}}}
$$

Kriteria penentuan kesimpulan terhadap pengujian perkembangan kemampuan anak dalam mengenal sains yaitu jika $\mathrm{t}_{\text {hitung }}>\mathrm{t}$ tabel atau nilai sig $<\alpha=0,05$ maka Ho ditolak yang berarti bahwa secara signifikan terdapat perkembangan kemampuan anak dalam mengenal konsep sains.

\section{HASIL DAN PEMBAHASAN}

Pelaksanaan pembelajaran pada anak kelompok B TK Pertiwi Lombe untuk mengenalkan konsep sains dilakukan sebanyak tiga kali pertemuan. Konten pembelajaran didesain sedemikian rupa agar tujuan pembelajaran sains tercapai melalui percobaanpercobaan sains yang sederhana dengan memanfaatkan kondisi lingkungan sekolah.

Pertemuan pertama, pembelajaran mengenalkan sains tentang tenggelam dan terapung. Guru menyiapkan alat dan bahan yang akan di butuhkan dalam pengamatan. Sebelum anak memasuki ruangan, guru telah meletakkannya di atas meja setiap kelompok sesuai dengan jumlah kelompok. Guru melakukan demonstrasi terlebih dahulu untuk menstimulasi anak agar penasaran dan melontarkan pertanyaan. Ketika guru melakukan percobaan dengan memasukan garam kedalam salah satu gelas berisi air lalu memasukan telur kemudian mengamati posisi telur, anak terlihat heran dan takjub melihat perbedaan posisi telur yaitu telur yang di celup diair putih berada didasar gelas sedangkan telur yang dicelup diair garam berada diatas permukaan air. Sebelum anak-anak bereksplorasi, guru mengajak anak mengamati alat dan bahan yang telah disediakan dengan cara memegang langsung, mencium, meraba atau menekannya untuk membedakan bahan-bahan yang disediakan. Kemudian guru mengajak melakukan percobaan terhadap bahanbahan yang telah disediakan. Sebagian anak masih terlihat kaku dan ketakutan menyentuh alat dan bahan yang telah disediakan meskipun guru telah mengarahkan anak-anak. Pada pertemuan pertama ini, hanya satu atau dua anak yang tertarik untuk melakukan percobaan, guru yang mendominasi mengungkapkan hasil percobaan, anak terlihat pasif, malu, takut disalahkan guru sehingga pembelajaran terkesan pasif.

Pertemuan kedua dalam pembelajaran sains ini tentang pencampuran warna primer (merah, kuning, biru) menghasilkan warna sekunder (hijau, jingga, ungu). Seperti pembelajaran sebelumnnya guru menyiapkan alat dan bahan yang akan di butuhkan dalam pengamatan. Sebelum anak memasuki ruangan, guru telah meletakkannya di atas meja setiap kelompok sesuai dengan jumlah kelompok. Guru melakukan berdemonstrasi untuk menstimulasi anak agar penasaran dan melontarkan pertanyaan. Ketika guru melakukan percobaan dengan mencampur warna biru 
kedalam gelas berisi air dan warna merah kedalam gelas yang berbeda kemudian hasil percampurannya digabungkan yaitu merah dan biru maka akan membentuk warna baru yaitu warna ungu. Melihat percobaan yang dilakukan guru maka anak-anak terlihat takjub dan menganggap seperti sulab. Guru menjelaskan hasil percobaan. Selanjutnya anak diajak untuk mengamati alat dan bahan dengan menyantuh, meraba, menyebutkan apa saja yang meraka lihat diatas meja. Tanpa mendengar aba-aba lagi anak segera melakukan percobaan untuk mencampur warna yang telah disediakan. Pada pertemuan ini sebagian anak mulai tertarik dan timbul rasa ingin tahu untuk melakukan percobaan-percobaan berikutnya.

Pertemuan ketiga dalam pembelajaran sains ini tentang mengamati benda mencair dan tidak mencair. Kelas telah siap untuk memulai pembelajaran sehingga guru melakukan demonstrasi untuk menstimulasi anak dengan memanaskan potongan lilin pada api kecil maka potongan lilin akan berubah menjadi cair yang tadinya padat. Melihat percobaan yang dilakukan guru maka anak-anak heran dan bertanya kepada guru karena menganggap peristiwa itu seperti sulap. Guru menjelaskan penyebabnya. Anak terlihat sangat senang, antusias, berlomba untuk menjawab pertanyaan guru bahkan ada anak yang melontarkan pertanyaan kepada guru jika tidak memahami. Anak melakukan percobaan dengan penuh hatihati sebab pertemuan ketiga ini, pembelajaran terlihat menantang karena menggunakan api kecil. Namun karena anak sudah terbiasa dengan percobaan sebelumnya maka pembelajaran dapat terkontrol dengan baik. Anak-anak sudah paham sehingga tanpa berebutan namun secara teratur anak-anak memindahkan bahan-bahan ke wadah yang telah disediakan. Pada saat mengkomunikasikan hasil percobaan anak terlihat semangat, selalu ingin menjadi yang terbaik serta berebutan ingin menjawab pertanyaan guru. Terkadang anak melontarkan pertanyaan yang membuat guru merasa kewalahan menjawab pertanyaan anak-anak. Pada pertemuan ini juga anak semakin tergugah, dan tertarik hatinya untuk mengikuti pembelajaran sains selanjutnya.

Penilaian perkembangan kemampuan anak untuk mengenal konsep sains dilakukan saat pembelajaran sedang berlangsung. Untuk data pre-test diambil pada pertemuan pertama pembelajaran dan data post-test diambil pada pertemuan ketiga. Hasil kemampuan anak untuk mengenal sains setelah mendapat pembelajaran sains sederhana dapat dilihat pada Tabel berikut.

Tabel 3. Kemampuan Anak Mengenal Sains

\begin{tabular}{ccc}
\hline Kategori & Banyaknya & Persentase \\
BSB & 11 & $55 \%$ \\
BSH & 8 & $40 \%$ \\
MB & 1 & $5 \%$ \\
BB & 0 & $0 \%$ \\
& Total & $100 \%$ \\
\hline
\end{tabular}

Hasil pada Tabel 3 di atas menunjukkan bahwa sebagian besar kemampuan anak untuk mengenal sains sudah sangat baik melalui pembelajaran dengan percobaan sains sederhana. Sedangkan untuk mengetahui perkembangan kemampuan sains anak akibat dari perlakuan pembelajaran dengan percobaan sains sederhana tersaji pada Gambar berikut.

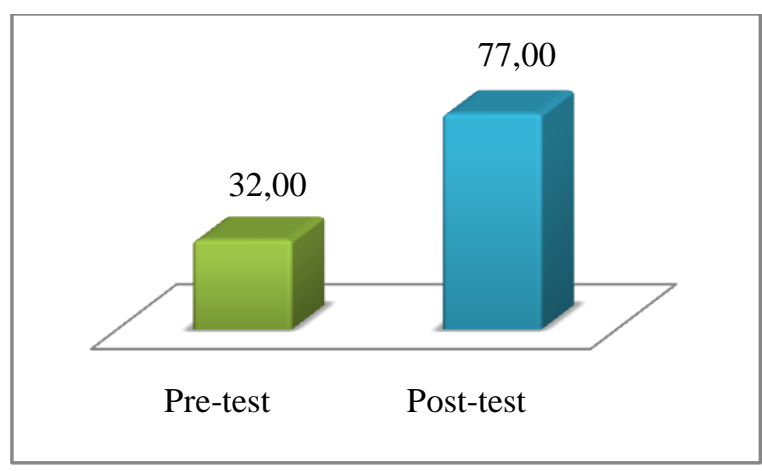

Gambar 1. Perkembangan Kemampuan Sains Anak

Kemampuan sains anak mengalami perkembangan dengan skor rata-rata 45 . Adanya perkembangan ini akibat dari setting pembelajaran yang dilakukan guru melalui pembiasaan pembelajaran dengan melakukan percobaan sains secara sederhana. Walaupun mengalami perkembangan perlu dilakukan uji statistik untuk melihat signifikansinya. Hasil uji paired sample t test dengan menggunakan SPPS menunjukkan dengan nilai sig $=0,000<0,05$, yang berarti, terdapat perkembangan yang cukup signifikan terhadap kemampuan anak untuk mengenal sains.

Anak yang diajar dengan pembelajaran sains memiliki kemampuan mengenal sainsnya 
lebih baik dibandingkan dengan anak yang diajar dengan pembelajaran konvensional. Hal ini di pertegas oleh Gijlers (2005) yang mengungkapkan bahwa siswa yang diajar pelajaran sains dalam kelompok-bekerja bersama dalam mengamati, menemukan langsung pembelajaran memiliki persepsi yang lebih positif penyelidikan keterampilan belajar dibandingkan dari siswa yang diajar pelajaran sains dengan metode konvensional. Hasil penelitian ini sejalan penelitian Wong et ell, (2010) bahwa perlakuan pembelajaran yang berbeda akan menghasilkan nilai yang berbeda pula dalam hal ini kelas eksperimen dan kontrol. Pemilihan metode pembelajaran yang efektif memiliki peran yang sangat penting. Pengaruh keaktifan dan keterampilan proses anak didik cukup signifikan terhadap prestasi belajar peserta didik, hal ini mengakibatkan prestasi belajarnya pun meningkat.

\section{SIMPULAN DAN SARAN}

\section{Simpulan}

Simpulan dari hasil penelitian ini diantaranya: (1) pelaksanaan pembelajaran untuk mengenalkan konsep sains pada anak kelompok B TK Pertiwi Lombe dilakukan melalui pembelajaran dengan percobaan sains secara sederhana sesuai dengan karakteristik anak dan kondisi sekolah, (2) kemampuan anak dalam mengenal sains pada kelompok B TK Pertiwi Lombe mengalami perkembangan dengan skor rata-rata 45 dan secara statistik cukup signifikan dengan nilai sig $=0,000<$ 0,05 .

\section{Saran}

Saran yang dapat dikemukakan dari hasil penelitian ini diantaranya: (1) bagi sekolah yang ingin mengenalkan sains pada anak TK B dengan tema lain maka dapat menggunakan pembelajaran dengan melakukan percobaan sains secara sederhana, (2) penelitian berikutnya diharapkan untuk menggunakan pembelajaran dengan melakukan percobaan sains secara sederhana pada tempat, berbagai wilayah sekolah yang berbeda agar keterterapannya pada kondisi yang berbeda dengan hasil yang sama

\section{DAFTAR PUSTAKA}

Akerson, V. L., Gayle, A., and Donnelly, L. A. 2011. The Importance of Teaching and Learning Nature of Science in the Early
Childhood Years. Journal Science \& Technologi, 20, 537-579.

Gijlers, H., and Tong de Jong. 2005. The relation between prior knowledge and students' collaborative discovery learning processes. Journal of Research in Science Teaching, 42, 264-282

Nugraha, A. 2008. Pengembangan Pembelajaran Sains Pada Anak Usia Dini. Bandung: Jilsi Poundation.

Osakwe, R. N. 2009. The Effect Of Early Childhood Education Experience On The Academic Performances Of Primary School Children. Studi Home comm Sci, 3(2): 143-147.

Sugiyono. 2010. Metode Penelitian Pendidikan. Bandung: Alfabeta

Supardi. 2013. Aplikasi Statistika Dalam Penelitian (Konsep Statistika Yang Lebih Komprehensif). Jakarta: Change Publication.

Suyanto, S. 2005. Konsep Desain Pendidikan Anak Usia Dini. Jakarta: Depdiknas.

Wong et al. (Eds). 2010. The Effectiviness of Inductive Discovery; Learning in Mathematics Classroom Graduate. Journal Computers of Education, 743747. 